\title{
BIOMASSZA SZUSZPENZIÓ SŰRÍTÉSI LEHETŐSÉGEINEK VIZSGÁLATA FLOTÁLÁSI MỨVELETTEL
}

\section{EXAMINATION OF BIOMASS SUSPENSION'S CONCENTRATION FACILITIES WITH FLOTATING OPERATION}

\author{
Hodai Zoltán ${ }^{1}$, Rippelné Pethő Dóra ${ }^{2}$, Horváth Géza ${ }^{3}$, Hanák László ${ }^{4}$, Bocsi Róbert ${ }^{5}$ \\ Pannon Egyetem, Mérnöki Kar, Vegyipari Müveleti Intézeti Tanszék, H-8200, \\ Magyarország, Veszprém, Egyetem utca 10. H-8201 Veszprém, Pf. 158. \\ 'hodaiz@almos.uni-pannon.hu \\ 2pethod@almos.uni-pannon.hu \\ 3horvathg@almos.uni-pannon.hu \\ ${ }^{4}$ hanakl@almos.uni-pannon.hu \\ 5ocsirobert@almos.uni-pannon.hu
}

\begin{abstract}
The use of biomass is widely researched, because it is an environmentally friendly solution to producing a variety of industries's raw materials, intent to use food supplements, cosmetics or oil industry. The biomass belong to the group of algae suspensions, which are produced in racewayponds, horizontal tubular or flat panel photobioreactor. One of the pivotal point is that appropriate proportion to concentrate the biomass, since the basic separation methods such as filtration, sedimentation, clarification, etc, are very costly, because large volume of suspension which is have relatively dilute concentration (1-2 $\mathrm{g} / \mathrm{dm}^{3}$ ) have to concentrating up to $30 \mathrm{~g} / \mathrm{dm}^{3}$.
\end{abstract}

The main point is examining the opportunity of froth flotation as a cost efficient concentrating and harvesting method on algae suspensions, which are produced in a special photobioreactor (PBR).

Keywords: algae technology, carbon dioxide absorption, photobioreactor, separation, flotation

\section{Összefoglalás}

A biomasszák felhasználását széles körben kutatják, hisz környezetkímélö megoldást jelenthet a különböző iparágak alapanyagainak előállítása szempontjából, legyen szó táplálék kiegészítőkről, kozmetikumokról vagy olajiparról. A biomasszák csoportjába tartoznak az algaszuszpenziók is, melyeket nyílt vízi vagy zárt rendszerben, reaktorokban állítanak elő. Az egyik sarkalatos pont a biomasszák megfelelő arányú sürítése, mivel az alap elválasztási műveletek, mint szürés, ülepítés, derítés, bepárlás, stb., igen költségesnek mutatkoznak, mivel nagy mennyiségű viszonylag híg 1-2 g/ $\mathrm{dm}^{3}$ koncentrációjú szuszpenziót kell akár $30 \mathrm{~g} / \mathrm{dm}^{3}$-re süríteni.

Speciális fotobioreaktorokban termesztett algaszuszpenziókon vizsgáljuk a habflotálást, mint gazdaságos sürítési lehetőséget, ezen belül több különböző tápoldatösszetételt és ennek hatását a szuszpenzió minőségén keresztül a mủveletre, valamint a vegyszerigényt és optimumot.

Kulcsszavak: algatechnológia, széndioxid elnyeletés, foto-bioreaktor, szeparáció, flotálás 


\section{Bevezetés}

Egyre nagyobb figyelmet kapnak az olyan technológiák, melyek a kibocsátott szennyezőanyagokat számunkra hasznos anyagokká alakítják át, így csökkentve a kibocsátás mennyiségét [1-4].

Energiatermelés szempontjából is a fotoszintetizáló mikroszkopikus élőlények (mikroalgák) jönnek elsősorban számításba, mert viszonylag gyorsan, nagy tömegben termeszthetők, termőtalaj igénye nélkül. A folyamat végterméke jelentős mennyiségü, kémiai kötésekben raktározott napenergiát tartalmaz [1, 5-6]. A technológia kritikus pontját a mikroalgaszuszpenzió besürítése jelenti a magas beruházási és üzemeltetési költségek és a nagy műveleti idők miatt [7, 8]. A betakarítási, szeparációs költségek meghaladhatják a teljes költség több mint $18 \%$-át is [9].

\section{Flotálás}

A flotálás az anyagok felületi adhéziós sajátságainak eltérésén alapuló dúsítási eljárás, amely különböző anyagok felületének a levegőhöz és vízhez való eltérő tapadásán alapul. A víz vagy levegő megtapadását a sejtek felületén, a megfelelö reagensek hozzáadásával, módosítani, azaz fokozni lehet. Ha légbuborékokat diszpergálunk a szuszpenzióba, ezekhez hozzátapadnak az anyagszemcsék, és a buborékokkal együtt felszállnak a szuszpenzió felszínére [10].

Alkalmas reagensek hozzáadásával a buborékok nem pattannak azonnal szét, hanem hosszabb-rövidebb ideig megmaradnak a szuszpenzió felszínén, ott többékevésbé tartós habot képezve.

Hatékony algasürítés eléréséhez általában flokkulálószerek, felületaktív anyagok adagolása is szükséges. Az elválasztott, mikroalgában dús szuszpenzióban (hab) az alga koncentrációja elérheti az 5-7 m/m\% értéket is $[10,11]$.
A mikroalgák flotálással történő besürítésére alkalmazott berendezéseknek, ill. konstrukciós változatoknak, a müveleti paraméterek sokaságán túlmenően, a fajlagos energiaigénye is nagyon különbözö [12].

A flotálás hatásfokát megvizsgálva, különböző felületaktív anyagok szerepét is tanulmányozzák a szakirodalmak $[13,14]$.

\section{Kísérleti rész}

\subsection{Habflotáláshoz összeállított kísér- leti berendezés}

Habflotálási kísérleteinkhez az alábbi készüléket állítottuk össze (1. ábral). A flotáló oszlop egy alul üvegfrittel ellátott üvegoszlop, $\mathrm{M}=105 \mathrm{~mm}$ magassággal, és $\mathrm{D}_{\text {belso }}=20 \mathrm{~mm}$ átmérővel. A fritt alá rotaméteren keresztül történik meg a gáz bevezetése változtatható térfogatárammal.

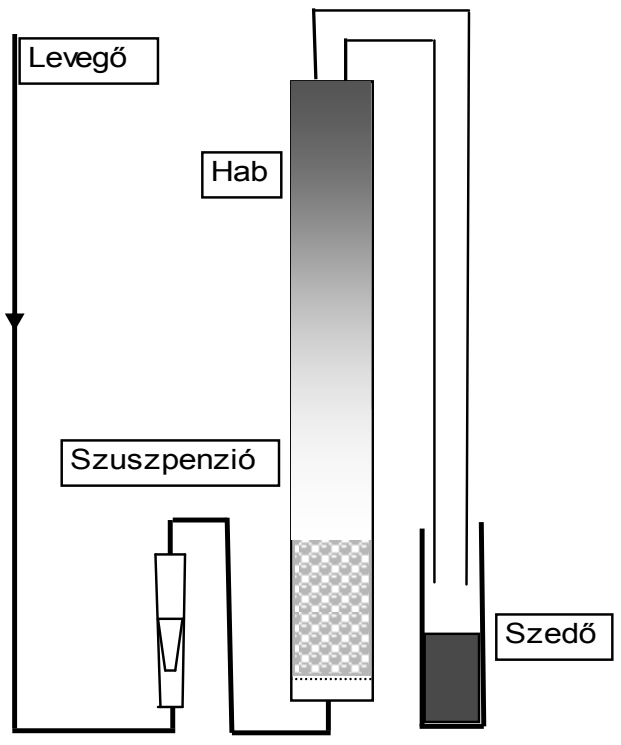

1. ábra. Habflotáló berendezés kapcsolási vázlata

Az üvegoszlopba $100-200 \mathrm{~cm}^{3}$ szuszpenzió térfogat tölthető be „kezelésre”, az oszlop tetejéhez csatlakoztatott cső a szedőedénybe vezeti a mikroalga sejtekben dús habot. 


\subsection{Flokkuláló szer, felületaktív anyag hatása}

Habflotálási kísérleteimhez a szabadtéri termesztésből frissen szüretelt mintákat használtam fel. Vegyszerként salétromsav $1 \mathrm{~mol} \quad \mathrm{HNO}_{3} / \mathrm{dm}^{3}$ koncentrációjú oldatát alkalmaztam.

A kezelt szuszpenziók térfogata 150 $\mathrm{cm}^{3}$, koncentrációjuk $4 \mathrm{~g} / \mathrm{dm}^{3}$, $\mathrm{pH}$ értékük pedig 9,8 .

A nagyobb hatásfokú flotálás érdekében 3,8-as pH-t állítottam be a HFx/1 kódú kísérleteimnél. A HFx/2 kóddal ellátott méréseim esetén a szuszpenziók koncentrációja $3,4 \mathrm{~g} / \mathrm{dm}^{3}, \mathrm{pH}$ értéke pedig 8,8 volt, a (salétromsavval) beállított $\mathrm{pH}$ értéke 4 . A kísérletek során alkalmazott levegöáramot 10 $\mathrm{dm}^{3} / \mathrm{h}$ értékre állítottam be, 25-30 perces müveleti idő mellett.
A 1. táblázatban látható, kiülepedett sürü zagy térfogata $5-6 \mathrm{~cm}^{3}$ a müvelet paramétereitől $(p H, V F, t)$ függetlenül. A kétszeresére hígított szuszpenziók esetén kb. 3 $\mathrm{cm}^{3}$ a zagy térfogata. Ezzel a zagytérfogattal számolva a múvelet végső térfogatsürítése $(\mathrm{VF})$ eredeti szuszpenziók $(3,5-4,0$ $\left.\mathrm{g} / \mathrm{dm}^{3}\right)$ esetén: $150 \mathrm{~cm}^{3} /\left(5-6 \mathrm{~cm}^{3}\right)=25-30$, kétszeres hígítás $\left(1,7-2,0 \mathrm{~g} / \mathrm{dm}^{3}\right)$ esetén pedig $150 \mathrm{~cm}^{3} /\left(3 \mathrm{~cm}^{3}\right)=50$.

Ezekkel a $V F$ értékekkel számolva a sürủ zagy alga-koncentrációja közelítőleg: az eredeti szuszpenziók esetén: (3,5-4,0 $\mathrm{g} / \mathrm{dm}^{3} /$ ) x 25-30 $90-120 \mathrm{~g} / \mathrm{dm}^{3}$, a hígított szuszpenziók esetén: $\left(1,7-2,0 \mathrm{~g} / \mathrm{dm}^{3} /\right)$ x 50 $\sim 85-100 \mathrm{~g} / \mathrm{dm}^{3}$. Így habflotálás és ülepítés alkalmazásával a sürú zagy koncentrációja: $C_{z a g y}=80-100 \mathrm{~g} / \mathrm{dm}^{3}$-nek adódik.

\section{1. táblázat. Habflotálási kísérletek eredményei}

\begin{tabular}{|c|c|c|c|c|c|c|c|}
\hline Mé- & $\mathrm{Hab}$ & tér- & Hab konc. & Maradék & konc. & $\mathrm{CF}$ & $\mathrm{V}$ \\
\hline HF1/ & 6,0 & & 64 & 0,5 & & 16 & 2 \\
\hline HF1/ & 7,3 & & 50 & 0,6 & & 20 & \\
\hline $\mathrm{HF} 2 /$ & 22 & & 27,5 & 0,8 & & 7 & 7 \\
\hline $\mathrm{HF} 2 /$ & 15 & & 25 & 0,4 & & 7,5 & 1 \\
\hline HF3/ & 16 & & 27,7 & 0,6 & & 7 & 1 \\
\hline HF3/ & 14 & & 30 & 0,2 & & 9 & 1 \\
\hline HF4/ & 8 & & 20 & 0,42 & & 10 & 1 \\
\hline HF4/ & 16 & & 23 & 0,3 & & 13 & 9 \\
\hline HF5/ & 32 & & 22,5 & 0,1 & & 6 & 5 \\
\hline HF5/ & 28 & & 20 & 0,2 & & 6 & 5 \\
\hline HF6/ & 39 & & 16 & 0,15 & & 4 & 4 \\
\hline HF6/ & 31 & & 18 & 0,3 & & 5 & 5 \\
\hline
\end{tabular}

\section{Következtetések}

A habflotálás kis energiaigényü $\left(0,1 \mathrm{MJ} / \mathrm{m}^{3}\right.$ szuszpenzió) és kis müveleti időkkel ( $\sim 30 \mathrm{~min})$ jellemezhető. De nem lehet elfelejteni a -bizonyos esetekbenszükséges vegyszerek, valamint felületaktív anyagok alkalmazását, ami csakúgy, mint a vegyszeres flokkulációs müveletek, költ- ségvonzattal járnak és környezetterhelést is jelent.

Felületaktív anyagok adagolása:10-30 $\mathrm{mg} / \mathrm{dm}^{3}$ dózissal történt a kísérletek során. Az így nyert sủrü zagy alga-koncentrációja közelítőleg: $\sim 90-120 \mathrm{~g} / \mathrm{dm}^{3}$, a hígított szuszpenziók esetén: $\sim 85-100 \mathrm{~g} / \mathrm{dm}^{3}$.

Az elökísérletek a habflotálásra, felületaktív anyagok adagolása nélkül is, rendkí- 
vül kedvező eredményeket adtak: a kihozatal $>90 \%$, térfogatsürítés: ( $p H=4$ értéken) $\sim$ 10-25, térfogatsürítés: ( $p H$ változtatás nélkül) $\sim 5$. A habban átvitt zagy koncentrációja: $\sim 20-50 \mathrm{~g}$ alga $/ \mathrm{dm}^{3}$.

\section{Köszönetnyilvánítás}

A kutatás a TÁMOP 4.2.4.A/2-11-12012-0001 Nemzeti Kiválóság Program címü kiemelt projekt keretében zajlott. A projekt az Európai Unió támogatásával, az Európai Szociális Alap társfinanszírozásával valósul meg.

\section{Szakirodalmi hivatkozások}

[1]D. Dah-Wei Tsai, R. Ramaraj, P. Honglay Chen: Growth condition study of algae function in ecosystem for $\mathrm{CO}_{2}$ bio-fixation, Journal of Photochemistry and Photobiology B: Biology, 2012, 27-34

[2]G. Venkata Subhash, Rashmi Chandra, S. Venkata Mohan: Microalgae mediated bioelectrocatalytic fuel cell facilitates bioelectricity generation through oxygenic photomixotrophic mechanism, Bioresource Technology, 2013, 644-653

[3] R. Slade, A. Bauen: Micro-algae cultivation for biofuels: Cost, energy balance, environmental impacts and future prospects, Biomass and Bioenergy, 2013, 29-38

[4] M. Rickman, J. Pellegrino, J. Hock, S. Shaw, B. Freeman: Life-cycle and techno-economic analysis of utility-connected algae systems, Algal Research, 2013, 59-65

[5] A. Ruiz-Martinez, N. Martin Garcia, I. Romero, A. Seco, J. Ferrer: Microalgae cultivation in wastewater: Nutrient removal from anaerobic membrane bioreactor effluent, Bioresource Technology, 2012, 247-253

[6] Sunja C., Nakyeong L., Seonghwan P., Jaecheul Y., Thanh Thao L., You-Kwan Oh, Taeho L.: Microalgae cultivation for bioenergy production using wastewaters from a municipal WWTP as nutritional sources, Bioresource Technology, 2013, 515-520

[7] Truc Linh Nguyen, D.J. Lee, J.S. Chang, J.C. Liu: Effects of ozone and peroxone on algal separation via dispersed air flotation, Colloids and Surfaces B: Biointerfaces, 2013, 246-250

[8] Ryan D., Andy A., Philip T. Pienkos: Techno-economic analysis of autotrophic microalgae for fuel production, Applied Energy, 2011, 3524-3531

[9] Benjamin T. S., Robert H. D.: Sedimentation of algae flocculated using naturallyavailable, magnesium-based flocculants, Algal Research1 2012, 32-39

[10] Edzwald JK: Algae, bubbles, coagulants, and dissolved air flotation. Water Sci Technol 27(10), 1993, 67-81

[11] Singh A, Nigam PS, Murphy JD: Mechanism and challenges in commercialisation of algal biofuels, Bioresour. Technol. 102 (1), 2011, 26-34

[12] Wiley P E, Brenneman K J, Jacobson A E.: Improved Algal Harvesting Using Suspended Air Flotation, Water Environ Res, 81, (7), 2009, 702-708

[13] Chen Y M, Liu JC, Ju YH : Flotation removal of algae from water, Colloids and Surfaces B, 12, 1998 49-55

[14] Levin G V, Gibor A,: Clendenning J R, Bogar F D: Harvesting of algae by froth flotation Applied Microbiology, 10, 1962, 169175 